\title{
The Presence of Other TB Cases in the Family as a Substantial Factor Influencing the Level of Knowledge and Perception of TB patients
}

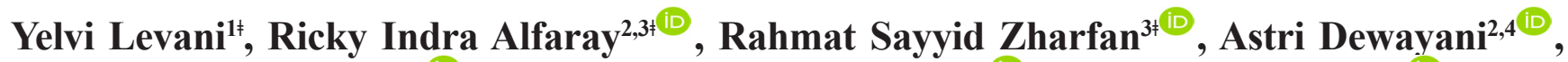 \\ Kartika Afrida Fauzia ${ }^{2,5}$, Batsaikhan Saruuljavkhlan ${ }^{2,6^{(\mathbb{D}}}$, Ayu Lidya Paramita ${ }^{(\mathbb{D})}$, Maya

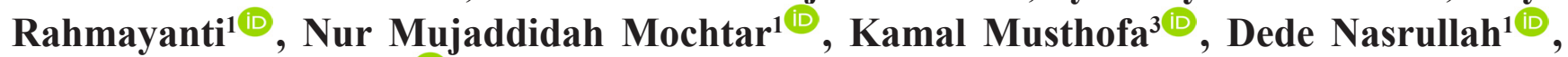 \\ Mohammad Subkhan ${ }^{*}$ (iD)
}

\begin{abstract}
${ }^{1}$ Faculty of Medicine, Universitas Muhammadiyah Surabaya, Surabaya, Indonesia
${ }^{2}$ Faculty of Medicine, Oita University, Yufu City, Oita Perfecture, Japan

${ }^{3}$ Faculty of Medicine Universitas Airlangga, Surabaya, Indonesia

${ }^{4}$ Department of Anatomy, Histology and Pharmacology, Faculty of Medicine, Universitas Airlangga, Surabaya, Indonesia

${ }_{5}^{5}$ Department of Public Health and Preventive Medicine, Faculty of Medicine, Universitas Airlangga, Surabaya, Indonesia

${ }^{6}$ Mongolian Institute of Medical Sciences, Ulaanbaatar, Mongolia
\end{abstract}

\section{A R T I C L E I N F O}

\section{Article history:}

Received 21 May 2021

Received in revised form 18 June 2021

Accepted 25 June 2021

Available online 30 June 2021

\section{Keywords:}

Tuberculosis,

Knowledge,

Perception,

Awareness.

\section{*) Corresponding author:}

doktersubkhan@gmail.com

†Yelvi Levani, Ricky Indra Alfaray and Rahmat Sayyid Zhafran contributed equality to this work.

\begin{abstract}
A B S T R A C T
Introduction: Indonesia is still among the top three contributors to the number of Tuberculosis (TB) patients in the world in 2017. The awareness about TB can be affected by the presence of other TB patients in the family. Perception and good knowledge in TB patients can increase obedience in treatment. We investigated the effects of knowledge and perception of other TB patients in the family environment to knowledge and perception of TB patients.

Methods: This study used cross-sectional design. Research respondents have taken using the consecutive sampling technique. Respondents were TB patients on category one anti-tuberculosis treatment at Siti Khadijah Sepanjang Hospital and several primary health centers in Sidoarjo region during February-March 2019. This study used a questionnaire which included sociodemographic, level of knowledge, and perception about TB.

Results: The number of respondents in this study was 50 people aged 22-67 years old. The level of knowledge of the respondents was mostly good (82\%) as well as perceptions regarding TB (78\%). Of the 50 patients, 17 patients (34\%) claimed some families also suffered from TB. The comparison between group with other TB patient and group without other TB patients in the family showed significantly different result in the level of knowledge $(p=0,000)$ and perception $(p=0,000)$. The presence of other TB cases in family increased the level of knowledge and perception regarding TB significantly.

Conclusion: The presence of other TB patients in the family environment can increase awareness so that it can increase the interest of TB patients to find information about TB.
\end{abstract}

\section{Introduction}

Toxo Tuberculosis (TB) is among the top ten diseases that cause death in the world. TB is caused by acidfast bacilli Mycobacterium tuberculosis. Based on WHO data, in 2017, 10 million people were suffering from $\mathrm{TB}$, and 1.6 million died. Not only adults that experience TB, but also children. In 2017, 1 million children were affected by TB, and 230,000 children died from TB. TB is a leading cause of death in people with HIV, where 300,000 HIV patients die from TB during 2017. Indonesia had the third highest number of TB cases in the world after India and China in $2017 .{ }^{1}$

Through the DOTS (Directly Observed Treatment, 
Short Course) program the incidence of TB has dropped 2\% annually globally. From 2000 to 2017 , as many as 54 million survivors through appropriate TB diagnosis and therapy. Even so, there are still significant problems that must be faced, namely MDR-TB (multidrug-resistant TB) with an estimated 558,000 new cases that are resistant to Rifampicin drugs. ${ }^{1}$ One of the leading causes of MDR-TB is a failure of therapy due to patient non-compliance in taking the medication. The subjects who were not completed therapy may need more extended medication regimens and may continue spreading the disease. ${ }^{2}$

Several factors have been reported that affect on therapeutic non-compliance including low socioeconomic, alcohol consumption, co-infection with HIV, male sex, homelessness, abuse of drugs, history of smoking, re-treatment cases, low level of knowledge and low level of interest in therapy.34 Some medical conditions are risk factors for TB and influence the results of TB therapy. These conditions including HIV infection, diabetes mellitus, malnutrition, smoking, and alcohol abuse. ${ }^{5}$ The awareness about TB can be affected by other TB patients in the family. Perception and good knowledge in TB patients can increase obedience in treatment. The main approach in assessing the level of knowledge and perception is through a questionnaire. To analyze this relationship, we conducted a study with a closed interview method using a questionnaire tool. The study was conducted in Siti Khadijah Hospital and several primary health centers in Sidoarjo region Indonesia during February - March 2019.

\section{Methods}

\section{Study design and subjects}

This study used a cross-sectional design. Respondents were TB patients on category one anti-tuberculosis treatment at Siti Khadijah Sepanjang Hospital and several primary health centers in Sidoarjo region during February - March 2019. Inclusion criteria were newly diagnosed pulmonary tuberculosis and aged more than 15 years old. The diagnosis was confirmed by positive sputum smear using the national guidelines for TB diagnosis and treatment. 6 Exclusion criteria were patients with mental illness and underlying chronic disease. A total of 50 patients were treated using category one anti-tuberculosis regiment; $300 \mathrm{mg}$ isoniazid, $450 \mathrm{mg}$ rifampicin, $1,500 \mathrm{mg}$ pyrazinamide, and $750 \mathrm{mg}$ ethambutol daily for two months. The treatment continued by $600 \mathrm{mg}$ isoniazid and $450 \mathrm{mg}$ rifampicin three times a week during the next four months.

\section{Data collection}

Research respondents have taken using the consecutive sampling technique. Patients were interviewed for the socio-demographic profiles, level of knowledge, and perception about TB using a semi-structured questionnaire.

\section{Knowledge and perception of TB}

The semi-structured questionnaire used in this study were adopted from an Indonesian study group of TB in NTT with modification. ${ }^{7}$ There were nine truefalse statements to assess the patient's knowledge, including etiology, mode of transmission, diagnosis, and treatment of TB. There were twelve questions of agree-disagree statements to evaluate patient's perception regarding subjective beliefs about TB disease. Every correct answer on knowledge and perception scored one while false answer scored 0 . A higher score indicated better understanding and personal belief.

\section{Statistical analysis}

Statistical analysis was done using SPSS Statistics (Statistical Package for the Social Science, Inc., Chicago, USA) for Windows version 11.5. To assess the relationship between the presence of other TB patients in the family with a level of knowledge and perception, we used Mc Nemar test. We Significant result if $\mathrm{p}<0.05$.

\section{Ethical approval}

Informed consent was obtained from all patients. The ethical approval for this study was obtained from the Ethical Committee of Siti Khodijah Hospital Sidoarjo Indonesia (No 005/KET-TPEP/II-2019).

\section{Results}

\section{Sociodemographic of patients}

Fifty respondents aged 22-67 years old were included in this study. In Table 1, there were 29 males (58\%) and 21 females $(42 \%)$. The number of respondents with high-level education (finished senior high school) was high $(68 \%)$. The number of respondents who finished junior high school was nine subjects $(18 \%)$. The number of respondents who finished elementary school was eight subjects (16\%). There was one $(2 \%)$ respondent not entering school. The number of respondents who had a job was 31 subjects $(62 \%)$, and the number of respondents who had not jobbed was 19 subjects (38\%). Most subjects were married (84\%). Of the 50 patients, 17 patients $(34 \%)$ claimed there were families who also suffered from TB.

Table 1. Characteristic of Sociodemographic

\begin{tabular}{lll}
\hline Variables & & \\
\hline Sex & Male (58\%) & Female (42\%) \\
\hline Level of education & High (68\%) & Low $(32 \%)$ \\
\hline Working & Yes $(62 \%)$ & No $(38 \%)$ \\
\hline Marital status & Married (84\%) & Single (16\%) \\
\hline $\begin{array}{l}\text { Another TB patient in } \\
\text { family }\end{array}$ & Yes (34\%) & No (66\%) \\
\hline
\end{tabular}

\section{Knowledge of patients about TB}

For general information, patients were asked about the main source of information regarding TB. The main sources of information about TB were from family $(42 \%)$, health workers $(38 \%)$, and information media $(20 \%)$. There were nine true-false statements 
to assess the patient's knowledge, including etiology, mode of transmission, diagnosis, and treatment of TB in Table $2 .{ }^{7}$ The average score was 8 . The level of knowledge was classified into two classes; low and high. The level of knowledge was low if the score below average. The level of knowledge was high if the score above average. The number of respondents who had high level of knowledge was 41 subjects $(82 \%)$, and the number of respondents who had low level of knowledge was nine subjects (18\%). Overall, the level of patient's knowledge about TB was good.

Table 2. Knowledge of patients about TB

\begin{tabular}{lcc}
\hline Questions & Correct & Incorrect \\
\hline The cause of TB is bacteria & $74 \%$ & $26 \%$ \\
\hline TB is a curable disease & $96 \%$ & $4 \%$ \\
\hline TB is a contagious disease & $92 \%$ & $8 \%$ \\
\hline TB is an airborne disease & $92 \%$ & $8 \%$ \\
\hline $\begin{array}{l}\text { TB patient should dispose sputum } \\
\text { in a close container }\end{array}$ & $96 \%$ & $4 \%$ \\
\hline $\begin{array}{l}\text { Closing mouth while coughing to } \\
\text { prevent transmission }\end{array}$ & $96 \%$ & $4 \%$ \\
\hline $\begin{array}{l}\text { TB is easily spread in a crowded } \\
\text { house }\end{array}$ & $94 \%$ & $6 \%$ \\
\hline $\begin{array}{l}\text { TB should be treated for at least six } \\
\text { months }\end{array}$ & $92 \%$ & $8 \%$ \\
\hline $\begin{array}{l}\text { TB is diagnosed by sputum } \\
\text { examination }\end{array}$ & $96 \%$ & $4 \%$ \\
\hline
\end{tabular}

\section{Perception of patients about TB}

There were twelve questions of agree-disagree statements to assess patient's perception regarding subjective beliefs about TB disease in Table $3 .^{7}$ The average score was 10 . The level of perception was classified into two classes; low and high. The level of perception was low if the score below average, and the level of perception was high if the score above average. The number of respondents who had a high level of perception was 39 subjects (78\%), and the number of respondents who had a low level of perception was 11 subjects $(22 \%)$. Overall, the level of the patient's perception of TB was good.

Table 3. Perception of patients about TB

\begin{tabular}{lcc}
\hline Questions & Agree & Disagree \\
\hline TB is life threatening disease for me & $88 \%$ & $12 \%$ \\
\hline TB is caused by a curse & $2 \%$ & $98 \%$ \\
\hline I have made sin therefore I got TB & $2 \%$ & $98 \%$ \\
\hline I am ashamed because I got TB & $40 \%$ & $60 \%$ \\
\hline $\begin{array}{l}\text { TB therapy is available at Puskes- } \\
\text { mas }\end{array}$ & $100 \%$ & $0 \%$ \\
\hline $\begin{array}{l}\text { TB patients must be isolated from } \\
\text { the community }\end{array}$ & $4 \%$ & $96 \%$ \\
\hline $\begin{array}{l}\text { TB needs serious treatment } \\
\text { I have to follow the treatment } \\
\text { routinely }\end{array}$ & $6 \%$ & $94 \%$ \\
\hline
\end{tabular}

\begin{tabular}{lll}
\hline $\begin{array}{l}\text { I can be cured if I treated at Pusk- } \\
\text { esmas }\end{array}$ & $4 \%$ & $96 \%$ \\
\hline $\begin{array}{l}\text { I am afraid of people gossiping me } \\
\text { when I go to Puskesmas }\end{array}$ & $12 \%$ & $88 \%$ \\
\hline $\begin{array}{l}\text { I am scared that my disease inter- } \\
\text { fered my social life }\end{array}$ & $20 \%$ & $80 \%$ \\
\hline $\begin{array}{l}\text { I am worried losing my job because } \\
\text { of my ilness }\end{array}$ & $18 \%$ & $82 \%$ \\
\hline
\end{tabular}

Relationship between the presence of other TB patients in the family environment with knowledge and perception of $\mathrm{TB}$

To assess the relationship between the presence of other TB patients in the family environment with knowledge and perception of TB, we used McNemar test. There was a significant result between the presence of other TB patients in the family with a level of knowledge $(\mathrm{p}<0.001)$ and perception $(p<0.001)$. It means, the comparison between with and without the presence of other TB patients in their family shown the different result in the level of knowledge and perception regarding TB.

\section{Discussion}

Knowledge and perception of TB played a significant role in treatment compliance. ${ }^{7}$ By definition, knowledge is fact, information, and skill acquired through experience or education to understand a subject. Perception is how something is regarded, understood, or interpreted. The knowledge of TB based on respondent's ability to recognize the etiology, route of transmission, diagnosis, and treatment. Perception usually reflects the level of understanding the disease. In this study, the overall level of knowledge and perception patients about TB was good enough.

Total of $92 \%$ respondents answered that $\mathrm{TB}$ is a contagious disease and transmitted via airborne. But only $72 \%$ of respondents explained that TB is caused by bacteria. $92 \%$ of respondents answered that TB is a curable disease and should be treated for six months. This is similar to the findings of the study conducted by Shivapujimath et al in India, in which $92 \%$ of TB patients said TB is curable after treatment started.8 Overall, the perception of patients about their disease was good. $100 \%$ of patients answered that TB treatment is available in Puskesmas (primary health care), but only $6 \%$ that answered TB needs severe treatment. Although most subjects no longer believe that TB is caused by sin or curse, there was $40 \%$ of TB patients who feel ashamed because of this disease. Feeling ashamed of TB patients is influenced by internal factor such as perception and external factor such as social stigma. The study from Shivapujimath et al in India revealed out of the 209 respondents, $51.2 \%$ of the respondents were stigmatized by the surrounding community. ${ }^{8}$ Our study has a better result in the level of knowledge and perception compared to the previous research in NTT 7 and reports from the Indonesian Ministry of Health. ${ }^{9}$

In this study, the respondents stated the primary sources of information about TB were from family, healthcare workers, and media. The comparison between a group with 
other TB patient and group without other TB patients in the family showed different result in the level of knowledge and perception. The presence of other TB case in family increased level of knowledge and perception regarding TB significantly. In line with our result, the previous study in Thailand demonstrated several reasons for the poor knowledge in TB patients. ${ }^{10}$ The low level of knowledge in TB patients was caused by no history of TB in family and never reading or attending public education about TB. ${ }^{10,11}$ Similar results reported in previous South African study. A presence of TB patient in family environment improves TB knowledge and even affects to patients by treatment efforts include TB testing, knowledge of dissemination and for care and support. Other study mentioned that being closely affiliated with TB patient enhances the ability to recognize signs and symptoms of TB.12 The presence of other TB patients in the family environment can increase awareness so that it can increase the interest of TB patients to find information about TB. Several other factors (i.e., occupational status and educational stage) also should be considered beside family history. ${ }^{13,14}$

Our finding that family and social media (62\%) could be influence to TB knowledge. In the other hand, poverty could be associated with TB testing and knowledge. Constantly receiving a social grant (TV, radio, social media) is suitable method to protective of knowing TB to the vulnerable people. Previous studies mentioned demographic factors such as people who live in less developed area might have higher rate of multi-drug resistant TB and extensively drug resistance $\mathrm{TB}$, have a lower rate of successful treatment than national rates. Due to this burden, constant social grant for TB education to any of vulnerable people including public clinics for other health condition and family members such as youth and among high school students.

Our study has several limitations. In this study, we did not compare between TB patients who completed treatment and defaulter. So, we could not assess how important the presence of other TB patients in the family environment complete the treatment. The total sample in this study was relatively small compared to others.

\section{Conclusion}

The awareness about TB can be affected by the presence of other TB patients in the family. Perception and good knowledge in TB patients can increase obedience in treatment. The presence of other TB patients in the family environment can raise awareness so that it can increase the interest of TB patients to find information about TB. Health care workers can use this factor to enhance the effectivity of health promotion in order to increase the perception and knowledge of TB in community especially from patients family or their related.

\section{Acknowledgement}

The authors want to thank Faculty of Medicine Universitas Muhammadiyah of Surabaya especially dr. H.M. Jusuf Wibisono, Sp.P(K), FCCP, FIRS as the dean and our father who always supports our idea and encourage us to do our best. Faculty of Medicine Universitas Muhammadiyah of Surabaya supports the funding of this research. The authors also want to tank all the participants and institutions who supports this study especially the Primary Health Cares of Surabaya-Sidoarjo, and Rumah Sakit Islam Siti Khodijah.
Finally, the authors also want to express our support and best wishes for Palestinian people who trying to survive in the middle of the conflict.

\section{Conflict of Interest}

The author stated there is no conflict of interest

\section{References}

1. Organization WH. Tuberculosis. Geneva, https:/www.who.int/ health-topics/tuberculosis 2018.

2. Nahid P, Dorman SE, Alipanah N, et al. Official American Thoracic Society/Centers for Disease Control and Prevention/Infectious Diseases Society of America Clinical Practice Guidelines: Treatment of Drug-Susceptible Tuberculosis. Clin Infect Dis an Off Publ Infect Dis Soc Am 2016; 63: e147-e195.

3. Muture BN, Keraka MN, Kimuu PK, et al. Factors Associated with Default from Treatment among Tuberculosis Patients in Nairobi Province, Kenya: A Case Control Study. BMC Public Health 2011; 11: 696 .

4. Madeira de Oliveira S, Altmayer S, Zanon M, et al. Predictors of Noncompliance to Pulmonary Tuberculosis Treatment: An Insight from South America. PLoS One 2018; 13: e0202593.

5. Organization WH. TB Comorbidities and Risk Factors. Geneva, 2018.

6. Indonesia DKR. Pedoman Nasional Penanggulangan Tuberkulosis. Jakarta, 2008.

7. Putera I, Pakasi TA, Karyadi E. Knowledge and Perception of Tuberculosis and the Risk to become Treatment Default among Newly Diagnosed Pulmonary Tuberculosis Patients Treated in Primary Health Care, East Nusa Tenggara: A Retrospective Study. BMC Res Notes 2015; 8: 238.

8. Shivapujimath R, Rao AP, Nilima AR, et al. A Cross-Sectional Study to Assess the Stigma Associated with Tuberculosis among Tuberculosis Patients in Udupi District, Karnataka. Indian J Tuberc 2017; 64: 323-326.

9. Indonesia BP dan PKDKR. Laporan Hasil Riset Kesehatan Dasar (RISKESDAS) Nasional 2010. Jakarta, 2010.

10. Kapella BK, Anuwatnonthakate A, Komsakorn S, et al. Directly Observed Treatment is Associated with Reduced Default among Foreign Tuberculosis Patients in Thailand. Int J Tuberc lung Dis Off J Int Union against Tuberc Lung Dis 2009; 13: 232-237.

11. Tachfouti N, Slama K, Berraho M, et al. The Impact of Knowledge and Attitudes on Adherence to Tuberculosis Treatment: A CaseControl Study in a Moroccan Region. Pan Afr Med J 2012; 12: 52.

12. Nyasulu P, Sikwese S, Chirwa T, et al. Knowledge, beliefs, and perceptions of tuberculosis among community members in Ntcheu district, Malawi. J Multidiscip Healthc 2018; 11: 375-389.

13. Alfaray RI, Mochtar NM, Zharfan RS, et al. Occupational Status and Educational Stage as a Valuable Factors Affecting Knowledge and Perception Level of Indonesian Tuberculosis Patient. Med Leg Updat 2021; 21: 1000-1008.

14. Subkhan M, Zharfan RS, Alfaray RI, et al. Association between Patient's Educational Degree with Level of Knowledge and Perception Regarding Pulmonary Tuberculosis. Med Leg Updat 2021; 21: 796-800. 